\title{
INFLUENCE OF THE ECONOMIC CRISIS ON THE IDENTIFICATION OF COUNTRY PROFILES WITHIN THE EUROPEAN TOMATO MARKET
}

\author{
María de las Mercedes CAPOBIANCO-URIARTE ${ }^{\circledR}$, Juan Carlos GÁZQUEZ-ABAD D, \\ Jaime DE PABLO-VALENCIANO ${ }^{\circledR}$, María del Pilar CASADO-BELMONTE ${ }^{*}{ }^{*}$
}

Department of Economy and Business, University of Almeria, Almeria, Spain

Received 02 May 2020; accepted 18 December 2020

\begin{abstract}
The objectives of this work are to determine the profiles of the countries that make up the European tomato consuming market and to observe if the economic-financial crisis (2007/2008) has influenced them. Both Lafay's economic indicators were applied and country profiles and subprofiles were identified through a multilevel two-stage cluster analysis. The empirical analysis covers the period from 2005 to 2016, separated into two periods, pre-crisis (2005-2010) and post-crisis (2011-2016). Most countries obtained import and export profiles that coincide in both indices, Except in Italy. Only one post-crisis profile change was detected, this being for Greece, from an importer to an exporter. As a result of the initial two-stage clustering analysis (both in the pre-crisis and post-crisis period), three clusters were obtained. At the first level of clustering, Italy is identified with a producer profile and Spain and the Netherlands with an exporter profile. At the second level of clustering of the initial larger group, two clusters were identified, Germany and the United Kingdom with an importing sub-profile, and France and Belgium with an exporting sub-profile. In the transition from the pre-crisis to the post-crisis period, Portugal changed from a producer sub-profile to an exporter sub-profile.
\end{abstract}

Keywords: agricultural trade, European tomato market, international downturn, Lafay's indexes, clustering, country profiles.

JEL Classification: Q17, J51, F44.

\section{Introduction}

The examination of the tomato trade should be analyzed in a landscape of turbulent agricultural markets characterized by uncertainties added to the traditionally highs risks facing agriculture as described by the Agricultural Outlook 2019-2028, developed jointly by the Organization for Economic Co-operation and Development (OECD) and the Food and Agriculture Organization of the United Nations (FAO). This environment depicts a global

\footnotetext{
*Corresponding author. E-mail: mbelmont@ual.es
} 
consumption of agricultural products that continues to increase, with developing countries remaining at the epicentre of most agricultural production growth. On the supply side, these include diseases, antimicrobial substance resistance, and extreme climatic changes. On the demand side, they include, food habits and health and sustainability issues. Trade prospects suggest that America will dominate exports, while China will lead import growth in Asia. According to OECD/FAO (2019), ongoing trade tensions are factors that could impact on international and domestic markets.

The availability of new types and varieties, new cultivation methods and the growing demand for vegetables have boosted world tomato production. According to Mexico's Panorama Agroalimentario of Fideicomisos Instituidos regarding the Agriculture report (FIRA, 2019), the volume harvested worldwide, total consumption, as well as average per capita consumption have shown an upward trend over the last decade. China remains the main producer and consumer. While the United States is the main global importer at country level, Mexico is the main external supplier of this vegetable worldwide, being its natural market the United States of America. However, the European Union is the main importer as a trading area (Capobianco-Uriarte et al., 2020). In an increasingly global world, the development of logistics and means of transport have enabled strong competition in the supply of vegetables to the European Union market from different production origins, both within and outside the EU (Agencia de Gestión Agraria y Pesquera de Andalucía, 2014).

In a global context, in which competitiveness has become a route to economic survival, the study of the composition of country profiles within a target market is an essential step. This type of analysis provides relevant information on the location of industrial clusters to be studied and should be carried out as a preliminary stage to obtaining indices of productivity and/or competitiveness and/or economic sustainability in countries that constitute an extensive target market such as the European Union. This work highlights the importance of exploring the profiles and sub-profiles in production, export or import of each of the countries that make up the European tomato market, for the selection of both the group of exporting competitors and the group of importing customers. The importance of the tomato as the vegetable with the greatest presence in international trade, and the European market as the main importer worldwide, underpin the relevance of the present study. The objective of this work is twofold. First, this study is aimed at describing and showing a classification of the European consumer market for tomatoes, namely, production, export and/or import profiles and sub-profiles of each of the countries that make up the European tomato market. Second, this study attempts to elucidate whether the $2007 / 8$ economic-financial crisis influenced changes in country profiles within the European tomato consumer market. To this end, different country profiles will be identified through Lafay's economic indexes and a multivariate cluster analysis applied to apparent tomato consumption variables at the European level (EU28) (i.e. production, import and export volumes). The disruption of global crisis may generate impact on macroeconomic variables of a country. In such a way, a global crisis could affect the profile of a country in makets. Thus, the identification of the effect of a crisis on country profiles may help to assess the impact of future crisis on specific markets. 
The main contribution of this study is the presentation of a new methodology called multilevel chained clustering, which makes it possible to determine country profiles and sub-profiles, combining the three variables of apparent consumption (production, export and import) of a product, therefore adjusting better to the reality of each country. So far, the application of the two versions of Lafay's economic indexes offers only a dichotomous and mutually exclusive classification of countries (net importer or net exporter), nor do they offer the producer profile as a result. The information obtained from this characterization will allow policy makers, trainers or consultants to profile the countries analyzed not dichotomously but with a wide range of profiles and sub-profiles combined and thus, design initiatives, tools and actions more suited to the reality of each country.

\section{Theoretical framework}

In the case of the European tomato market, the design of an index system of productivity and/or export competitiveness and/or economic sustainability requires a previous stage so as to determine objectively both the group of exporter countries competing in the European tomato market and the intra-Community client markets that import tomatoes.

Several works have studied the international tomato market in the European Union since 2010 (De Pablo-Valenciano et al., 2012; De Pablo Valenciano \& Giacinti Battistuzzi, 2012; Lombardi et al., 2016; De Pablo Valenciano \& Giacinti Battistuzzi, 2016; Bashimov, 2016; De Pablo Valenciano et al., 2017; Capobianco Uriarte et al., 2017; Pérez Mesa et al., 2018; Jurkènaitè \& Paparas, 2020; Álvarez, 2020; Capobianco Uriarte et al., 2020). It is worth mentioning the work of Pérez Mesa et al. (2018) that offers a network approach to differentiate the import countries from the export countries in the European context. The study used the software Gephi to identify and analyze the direction of the commercial flows between European countries, taking into account only import and export volumes.

To the best of authors' knowledge, there are no previous studies that deal with the country classification in order to accurately determine the selection of the group of countries competing on the European market and the intra-Community client markets that import tomatoes.

\section{Methodology}

\subsection{Variables}

The consumer market is associated with the concept of apparent consumption. It is estimated on the basis of domestic production, the trade balance and consumption of inventories. In the case of perishable products, apparent consumption is equal to the availability of such products since there are no inventories or stocks. The variables that make up the definition of apparent consumption of a given good (Eq. (1)) were selected according to the Office of Agricultural Studies and Policies (2012): 


\subsection{Database}

For this study of the European market for tomatoes a database was constructed with information from two databases belonging to the United Nations using the tariff code [0702 Tomatoes, Fresh] in both cases. FAOSTAT (2018) for production volume data [kg] and COMTRADE (2018) for international trade data (import volumes [kg] and export volumes [kg]).

\subsection{Lafay's economic indices for the determination of net exporter/importer profiles}

The first indicator (IL) was formulated by Lafay (1979), to measure the degree to which the country has a comparative advantage for a given product or service that makes it a natural exporter of that product (Durán Lima \& Alvarez, 2011). This indicator belongs to the family of indicators of the "specialization index" type. This index is obtained through the quotient between the production of the good and its apparent consumption (production plus imports minus exports, Eq. (2). Trejos (2008) indicates that, if this value is higher than the unit, the country is a net exporter with respect to the product analyzed, and the higher level reached indicates that exports gain importance as a destination of domestic production of the product analyzed.

$$
I L_{i}^{k}=\frac{P_{i}^{k}}{P_{i}^{k}+M_{i}^{k}-X_{i}^{k}},
$$

where: $P_{i}^{k}$ is the item production $k$ in country $i, M_{i}^{k}$ denotes imports from country $i$ of product $k$, and $X_{i}^{k}$ are exports for the product $k$ in the country $i$ for a certain period of time.

Crespo Faustino (1989) highlights that this Lafay indicator reveals the relationship between an economy and the rest of the world; that is to say, the weight of the product (or group of products) in the domestic market. If the resulting value is greater than 1 , the country is a net exporter of the good in question, and it increases as production for exports increases. If the value is less than 1 , the country is a net importer.

Later, Lafay (1992) presented the Trade balance index (TBI). This TBI index is used to analyze whether a country is specialized in exports (as a net exporter) or imports (as a net importer) for a specific group of products. This index is defined in the same way as the previous one but takes into account only two of the three variables of apparent consumption, imports and exports. This index is obtained through the quotient between the difference of exports and imports and the sum of them (Eq. (3)):

$$
T B I_{i k}=\frac{X_{i}^{k}-M_{i}^{k}}{X_{i}^{k}+M_{i}^{k}},
$$

where: $M_{i}^{k}$ are imports of product $k$ by country $i$ and, $X_{i}^{k}$ are exports for a product $k$ in the country $i$ during a given period of time.

The values in the TBI range start from -1 to +1 . In the case of a TBI equal to -1 , it indicates that a country only imports, whereas if the TBI is equal to +1 , it is a country that only exports. In fact, when a country does not have imports and exports, the index is not defined. 
A country is deemed as a "net importer" in a specific product group if the TBI value is negative, and as a "net exporter" if the TBI has positive value (Smutka et al., 2018).

\subsection{Two-stage multivariate clustering analysis}

Cluster analysis is a multivariate technique whose main objective is to classify, in this case, objects (country cases) forming groups or clusters that are as homogeneous as possible within themselves and heterogeneous among themselves (Hair et al., 2018). In other words, this classification serves to detect and describe subgroups of subjects or homogeneous cases according to the values observed within an apparently heterogeneous group (Rubio-Hurtado \& Vila-Baños, 2017).

Within the different cluster analysis techniques, bi-stage analysis has been selected because it is an exploration tool designed to discover the natural groupings of a data set (Pérez, 2011). This two-stage analysis was developed by Chiu et al. (2001) for the analysis of large data sets (Bacher et al., 2004). This two-phase algorithm includes several features that make it different from traditional clustering techniques (Pérez, 2011). The main distinguishing factor is the automatic selection of the optimal number of clusters by comparing the values of a model selection criterion for different cluster solutions. In this way, applying two-stage clustering ensures the use of a totally objective cluster selection tool, without involving the researcher's decision making. All calculations were carried out using IBM's SPSS computer tool.

Subsequently, in cluster analysis, one of the key aspects is the choice of the measure to be used to quantify the distance between the elements. In this work, the Euclidean distance was selected as the most appropriate measure for calculating dissimilarity between clusters due to the inherent advantages. For the application of the Euclidean distance to continuous variables, being normal or independent is not necessary (Rubio-Hurtado \& Vila-Baños, 2017). However, this distance is not invariant with respect to the data metrics, since the differences between variables with very high scores may cancel out the differences between variables with very low scores.

To classify European countries into groups, in which their differences were maximum in all three variables simultaneously, a two-stage cluster analysis was carried out to estimate the cluster centres in each standardized variable. In the two-stage cluster analysis, internal empirical checks indicate that this procedure is quite robust, even when conditions of independence and normality for the variables are not met. However, despite its robustness, in the two-stage cluster, the results are sensitive to the order of cases (Rubio-Hurtado \& Vila-Baños, 2017), so the stability of the solution obtained was tested with the cases ordered in different random orders. This two-stage algorithm also carries out the classification of the default variables, which is essential if the Euclidean distance is implemented.

\subsection{Selection of periods for the study of the influence of the global economic- financial crisis $2007 / 2008$}

The study of the influence of the 2007/2008 economic-financial crisis on the European tomato market was considered relevant because this crisis shook the world economy in 2007/2008 and caused a global recession in 2009 that led to the largest contraction in world trade in 
more than 70 years. The growth rate of trade had already slowed from $6.4 \%$ in 2007 to $2.1 \%$ in 2008 (Figure 1), but the $12.2 \%$ contraction in 2009 is unprecedented in recent history (WTO, 2014). The analysis of the influence of the global economic-financial crisis of $2007 / 2008$ on the international horticultural market took into consideration that it affected international trade in goods and services with a temporary gap of about one year. For this reason, this longitudinal study, which covers the period from 2005 to 2016 , will analyse the variables comparatively in a pre-crisis period 2005-2010 and in a post-crisis period 20112016. In this way, the pre-crisis period will support the drastic fall in the exchange of goods in 2009, together with the rebound effect of 2010 (Figure 1).

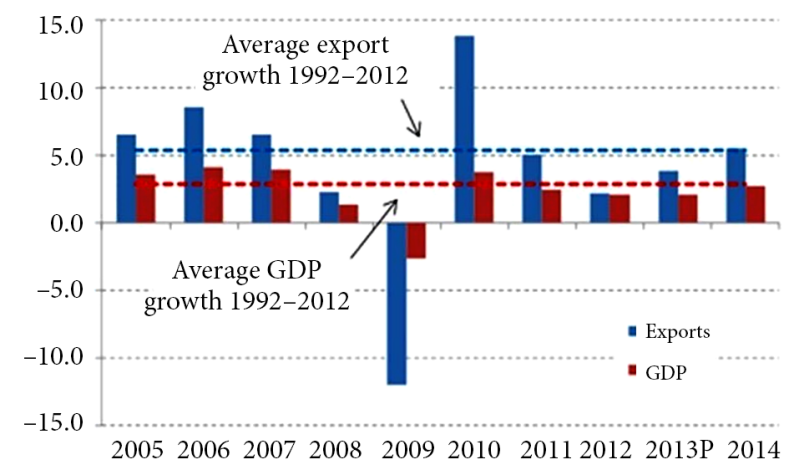

Figure 1. Volume of world trade in goods 2005-2014 (source: World Trade Organization (2014)

\section{Results}

\subsection{Application of Lafay's indices}

In Table 1, the results of both Lafay's indices ( and ) applied to pre-crisis and post-crisis samples are shown comparatively. The application of both Lafay's indices enables the profiles to be identified for each of the countries that make up the European tomato market, but only for two of the three variables used (import or export).

Table 1. Identification of profiles in the countries of the European tomato market Pre-crisis (2005-2010) and Post-crisis (2011-2016) (source: own elaboration based on COMTRADE, 2018

\begin{tabular}{|l|c|c|c|c|l|}
\hline \multirow{2}{*}{ Country/year } & \multicolumn{2}{|c|}{ (Lafay, 1979) } & \multicolumn{2}{c|}{ (Lafay, 1992) } & \multirow{2}{*}{ Profile identification } \\
\cline { 2 - 5 } & Pre-crisis & Post-crisis & Pre-crisis & Post-crisis & \\
\hline Austria & 0.50 & 0.57 & -0.76 & -0.74 & Importer \\
\hline Belgium & 2.19 & 2.19 & 0.46 & 0.42 & Exporter \\
\hline Bulgaria & 0.79 & 0.74 & -0.87 & -0.89 & Importer \\
\hline Croatia & 0.75 & 0.78 & -0.96 & -0.67 & Importer \\
\hline Cyprus & 0.98 & 0.96 & -0.86 & -0.96 & Importer \\
\hline Czech Republic & 0.22 & 0.11 & -0.76 & -0.81 & Importer \\
\hline Denmark & 0.32 & 0.26 & -0.95 & -0.92 & Importer \\
\hline
\end{tabular}


End of Table 1

\begin{tabular}{|c|c|c|c|c|c|}
\hline \multirow{2}{*}{ Country/year } & \multicolumn{2}{|c|}{ (Lafay, 1979) } & \multicolumn{2}{|c|}{ (Lafay, 1992) } & \multirow{2}{*}{ Profile identification } \\
\hline & Pre-crisis & Post-crisis & Pre-crisis & Post-crisis & \\
\hline Estonia & 0.34 & 0.27 & -0.98 & -0.98 & Importer \\
\hline Finland & 0.64 & 0.59 & -0.98 & -0.99 & Importer \\
\hline France & 0.67 & 0.66 & -0.50 & -0.40 & Importer \\
\hline Germany & 0.09 & 0.10 & -0.90 & -0.94 & Importer \\
\hline Greece & 0.99 & 1.01 & -0.59 & 0.32 & $\begin{array}{l}\text { Profile change } \\
\text { Importer } \rightarrow \text { Exporter }\end{array}$ \\
\hline Hungary & 0.91 & 0.92 & -0.78 & -0.63 & Importer \\
\hline Ireland & 0.24 & 0.14 & -0.86 & -0.95 & Importer \\
\hline \multirow[b]{2}{*}{ Italy } & 1.00 & 1.00 & & & Unspecified \\
\hline & & & 0.04 & -0.08 & $\begin{array}{l}\text { Profile change } \\
\text { Exporter } \rightarrow \text { Importer }\end{array}$ \\
\hline Latvia & 0.31 & 0.31 & -0.86 & -0.65 & Importer \\
\hline Lithuania & 0.19 & 0.41 & -0.21 & -0.11 & Importer \\
\hline Luxembourg & 0.02 & 0.02 & -0.87 & -0.83 & Importer \\
\hline Malta & 0.96 & 0.90 & -0.99 & -1.00 & Importer \\
\hline Netherlands & 3.70 & 23.48 & 0.64 & 0.64 & Exporter \\
\hline Poland & 0.98 & 0.95 & -0.09 & -0.18 & Importer \\
\hline Portugal & 1.10 & 1.06 & 0.62 & 0.54 & Exporter \\
\hline Romania & 0.93 & 0.93 & -0.97 & -0.93 & Importer \\
\hline Slovakia & 0.71 & 0.42 & -0.58 & -0.75 & Importer \\
\hline Slovenia & 0.24 & 0.39 & -0.86 & -0.71 & Importer \\
\hline Spain & 1.21 & 1.24 & 0.68 & 0.75 & Exporter \\
\hline Sweden & 0.16 & 0.14 & -0.98 & -0.97 & Importer \\
\hline United Kingdom & 0.17 & 0.19 & -0.98 & -0.98 & Importer \\
\hline
\end{tabular}

As can be seen in Table 1, both indices identified most European countries, 22 out of 28 (78.57\%), as net importing countries. Only Belgium, Spain, the Netherlands and Portugal (14.28\%) were identified as net exporters by both Lafay's indexes. In Italy, the (Lafay, 1979) was inconsistent in profiling in both periods. Finally, two pre-crisis and post-crisis profile changes were detected. First, the (Lafay, 1992) detected a change in profile in Italy from exporter to importer. Second, both indices detected a profile change in Greece, from initial identification as a net importer, to a net exporter in the post-crisis period. Due to the results obtained in the case of Italy, the indices are divergent in their results.

\subsection{Two-stage multilevel chain-linked clustering}

This section presents the results obtained in the two-stage multilevel chain-linked clustering. This methodological innovation was made in the traditional clustering methodology because 
one of the conglomerates was extensive and with numerous outliers, to which the two-stage clustering algorithm was applied again obtaining a second level of clustering.

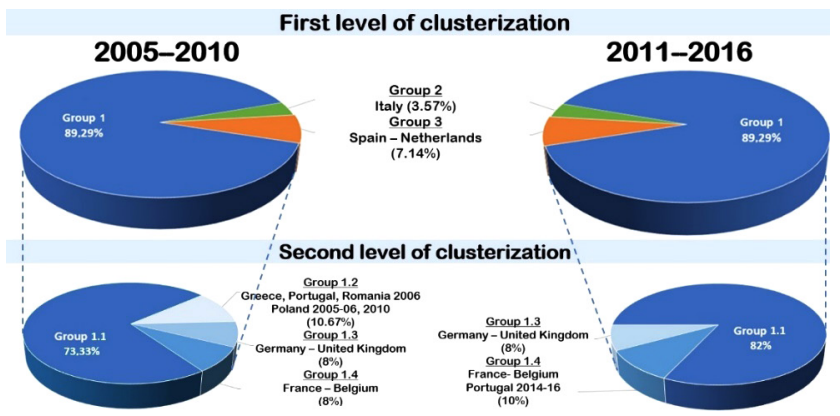

Figure 2. Chained clusters obtained through the two-stage cluster analysis (2005-2010 vs 2011-2016) (source: own elaboration)

\subsubsection{Pre-crisis period (2005-2010)}

In the pre-crisis sample, the two-stage algorithm automatically determined the number of clusters to be three. The quality of the cluster was 0.8 , indicating that the solution obtained is satisfactory, i.e. the data reflect reasonable or solid evidence that a cluster structure exists according to the assessment of Kaufman and Rousseeuw (1990).

The most numerous cluster was identified as cluster 1 (with more than $89 \%$ of the cases analyzed), grouping most European countries (Figure 2). Cluster 2 was made up of Italy only. Finally, cluster 3 consisted of only two countries (the Netherlands and Spain).

The characterization of the identified clusters can be completed through the information provided by ANOVA (Table 2) and the Bonferroni Multiple Comparison Test (Table 3). The analysis of variance (ANOVA) was performed to check whether the variables showed statistically significant differences between each cluster at the first level of clustering (Table 2). The differences between the three clusters in only two of the variables were statistically significant, export volumes $[\mathrm{F}(2,165)=1,041,229 ; \mathrm{p}(0,000)]$ and production $[\mathrm{F}(2,165)=349,895$; $\mathrm{p}(0,000)]$.

Table 2. Cluster centres and ANOVA for two-stage analysis at the first pre-crisis clustering level (source: own elaboration based on COMTRADE, 2018)

\begin{tabular}{|l|c|c|c|c|c|}
\hline \multirow{2}{*}{ Volumes $[\mathrm{Kg}]$} & \multicolumn{3}{|c|}{ Mean (Standard deviation) } & \multicolumn{2}{c|}{ ANOVA } \\
\cline { 2 - 6 } & Cluster 1 $(n=150)$ & Cluster 2 $(n=6)$ & Cluster 3 $(n=12)$ & $\mathrm{F}^{*}$ & Sig. \\
\hline Production & $\begin{array}{c}230,248,186 \\
(400,122,104)\end{array}$ & $\begin{array}{c}6,491,375,167 \\
(476,871,961)\end{array}$ & $\begin{array}{c}2,518,570,417 \\
(1,891,341,594)\end{array}$ & 349,895 & 0.000 \\
\hline Imports & $\begin{array}{c}93,717,124 \\
(167,127,676)\end{array}$ & $\begin{array}{c}99,077,125 \\
(17,383,928)\end{array}$ & $\begin{array}{c}184,082,203 \\
(46,338,997)\end{array}$ & 1,788 & 0.171 \\
\hline Exports & $\begin{array}{c}27,069,287 \\
(54,609,979)\end{array}$ & $\begin{array}{c}107,930,708 \\
(13,842,119)\end{array}$ & $\begin{array}{c}924,273,127 \\
(154,759,956)\end{array}$ & $1,041,229$ & 0.000 \\
\hline
\end{tabular}

Note: ${ }^{\star} \mathrm{df}$ between groups $=2$ and $\mathrm{df}$ within groups $=165$. 
Once it has been determined that there are differences between the means, the post hoc range tests (Bonferroni Test) enable us to determine which means differ. In such a way, homogeneous subsets of means that do not differ from each other are identified. At the first level of clustering, the variable with the greatest significant difference is export volume (Table 2) and the highest mean for this variable is presented by cluster 3 (composed of the Netherlands and Spain). In Table 4 on cluster characterization, cluster 3 can be identified with a main export profile. With the additional information in Table 3, a significant difference is observed between cluster 3 and the two remaining clusters and no significant difference is found between clusters 1 and 2 .

Table 3. Multiple comparisons (Bonferroni) at the first level of pre-crisis clustering (source: own elaboration based on COMTRADE, 2018)

\begin{tabular}{|c|c|c|c|c|}
\hline $\begin{array}{c}\text { Cluster } \\
i\end{array}$ & $\begin{array}{c}\text { Cluster } \\
j\end{array}$ & $\begin{array}{c}\text { Production Volume }[\mathrm{Kg}] \\
\text { Sig. }\end{array}$ & $\begin{array}{c}\text { Imports Volume }[\mathrm{Kg}] \\
\text { Sig. }\end{array}$ & $\begin{array}{c}\text { Exports Volume }[\mathrm{Kg}] \\
\text { Sig. }\end{array}$ \\
\hline \multirow{2}{*}{1} & 2 & 0.000 & 1.000 & 0.010 \\
\cline { 2 - 5 } & 3 & 0.000 & 0.181 & 0.000 \\
\hline 2 & 3 & 0.000 & 0.862 & 0.000 \\
\hline
\end{tabular}

The variable volume of production presents the highest average value in cluster 2 (Italy) (Table 2). This conglomerate (Cluster 2) was able to be identified as mainly a producer and secondarily as an exporter (Table 5). According to the Bonferroni Test for the production variable, all the clusters are different from each other (Table 3).

Continuing at the first level of cluster, within the three conglomerates obtained, specific profiles of pure production and export could be identified for the different European countries. However, the profile of the numerous cluster 1 cannot be determined. In the pre-crisis period, no temporarily differentiated profiles were found in this analyzed period. That is, the entire economic periods of each country were grouped within the same clusters. Table 4 shows the main profiles of each cluster at the first level of clustering.

Table 4. Characterization of the clusters of the first level of pre-crisis chained cluster (source: own elaboration based on COMTRADE, 2018)

\begin{tabular}{|c|c|}
\hline \multicolumn{2}{|c|}{$\begin{array}{c}\text { Cluster } 1(\mathrm{n}=150) \\
\text { Main profile Not DETERMINED }\end{array}$} \\
\hline \multicolumn{2}{|c|}{$\begin{array}{c}\text { Austria. Belgium. Bulgaria. Croatia. Cyprus. Czech Republic. Denmark. Estonia. Finland. Greece. } \\
\text { Hungary. Ireland. Latvia. Lithuania. Luxembourg. Malta. Poland. Portugal. Romania. Slovakia. } \\
\text { Slovenia. Sweden. France. Germany and United Kingdom }\end{array}$} \\
\hline $\begin{array}{c}\text { Cluster } 2(n=5) \\
\text { Main Profile PRODUCER } \\
\text { Sub-profile EXPORTER }\end{array}$ & $\begin{array}{c}\text { Cluster } 3(n=10) \\
\text { Main profile EXPORTER } \\
\text { Sub-profile PRODUCER }\end{array}$ \\
\hline Italy & Netherlands and Spain \\
\hline
\end{tabular}

Through the analysis of the box diagrams (Figures 3, 4 and 5), each cluster identified with a main profile can be characterized. In cluster 2 (Italy) the production volume variable has the most weight (Figure 3). In cluster 3 (Netherlands and Spain) the export volume variable 
has the most weight (Figure 5). In cluster 1 (other European countries), although the weight of one of the input variables is not as evident as in the previous clusters, it can be seen (Figure 4 ) that the import volume variable has greater weight than the other variables.

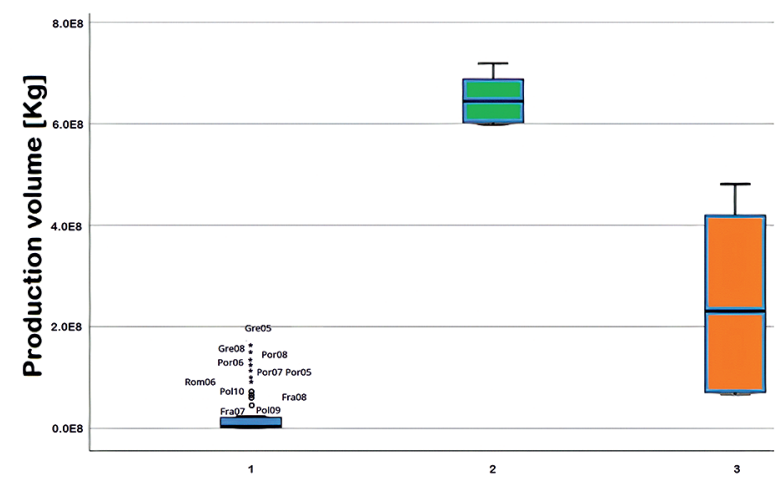

Figure 3. Box diagram of the pre-crisis production variable according to the clusters of the first two-stage clustering level (source: own elaboration)

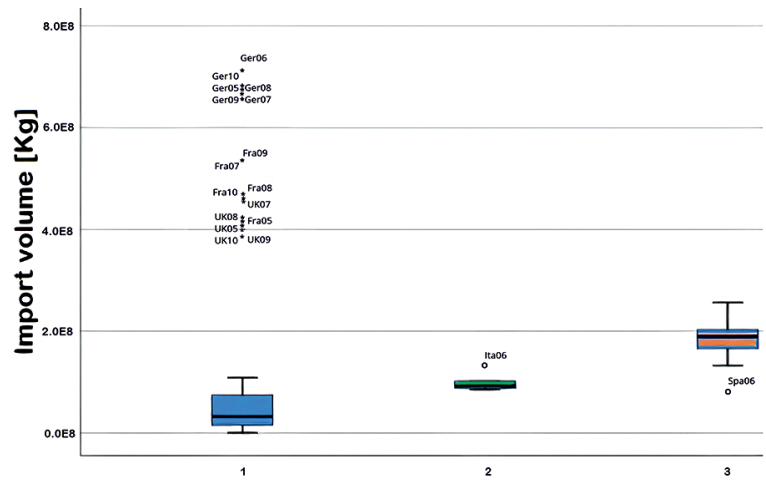

Figure 4. Box diagram of the pre-crisis import variable according to the clusters of the first two-stage clustering level (source: own elaboration)

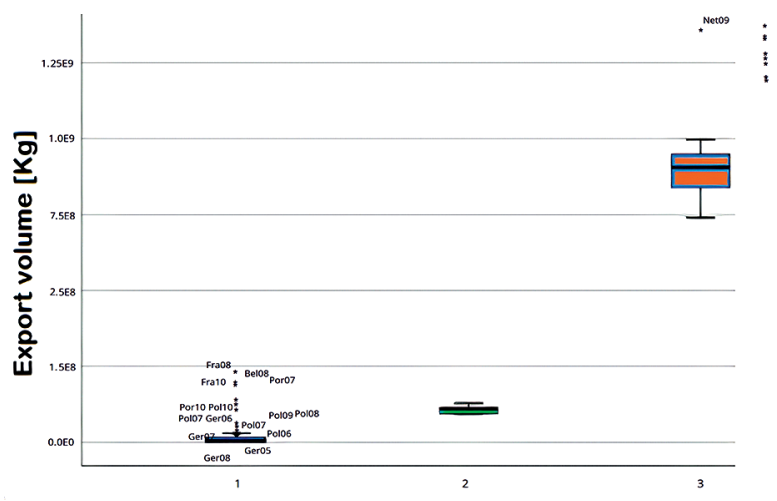

Figure 5. Box diagram of the pre-crisis export variable according to the clusters of the first two-stage clustering level (source: own elaboration) 
In the box diagrams for the clusters in the three input variables (Figures 3, 4 and 5) a high number of outliers in cluster 1 are observed. For this reason, and in order to achieve a more nuanced classification, the same sorting technique was again applied to the largest cluster in order to obtain sub-profiles from other country groups that maximise their inter-group differences and minimise their intra-group ones. In other words, two-stage clusters were created and two levels of clustering were obtained.

At the second level of clustering, the algorithm automatically determined the number of clusters as being four (the clustering algorithm was applied only for the selection of cases from cluster 1 of the first level of clustering). The quality of the cluster was lower in this case (0.7), although the solution obtained remained satisfactory (Kaufman \& Rousseeuw, 1990).

Table 5. Cluster centres and ANOVA for two-stage analysis at the second pre-crisis clustering level (source: own elaboration based on COMTRADE, 2018)

\begin{tabular}{|l|c|c|c|c|c|c|}
\hline \multirow{2}{*}{$\begin{array}{c}\text { Volumes } \\
{[\mathrm{Kg}]}\end{array}$} & \multicolumn{4}{|c|}{ Mean (Standard deviation) } & \multicolumn{2}{c|}{ ANOVA } \\
\cline { 2 - 7 } & $\begin{array}{c}\text { Cluster 1.1 } \\
(n=110)\end{array}$ & $\begin{array}{c}\text { Cluster 1.2 } \\
(n=16)\end{array}$ & $\begin{array}{c}\text { Cluster 1.3 } \\
(n=12)\end{array}$ & $\begin{array}{c}\text { Cluster 1.4 } \\
(\mathrm{n}=12)\end{array}$ & $\mathrm{F}^{*}$ & Sig. \\
\hline $\begin{array}{l}\text { Produc- } \\
\text { tion }\end{array}$ & $\begin{array}{c}83,197,609 \\
(175,832,712)\end{array}$ & $\begin{array}{c}1,199,663,438 \\
(333,903,455)\end{array}$ & $\begin{array}{c}74,250,833 \\
(13,127,910)\end{array}$ & $\begin{array}{c}441,655,500 \\
(227,056,351)\end{array}$ & 158,222 & 0.000 \\
\hline Imports & $\begin{array}{c}31,864,372 \\
(27,231,691)\end{array}$ & $\begin{array}{c}39,711,265 \\
(29,921,647)\end{array}$ & $\begin{array}{c}546,861,456 \\
(135,402,073)\end{array}$ & $\begin{array}{c}279,564,167 \\
(217,389,324)\end{array}$ & 199,616 & 0.000 \\
\hline Exports & $\begin{array}{c}5,383,121 \\
(12,063,829)\end{array}$ & $\begin{array}{c}67,160,553 \\
(63,329,104)\end{array}$ & $\begin{array}{c}20,175,462 \\
(16,190,032)\end{array}$ & $\begin{array}{c}179,297,952 \\
(29,151,575)\end{array}$ & 196,370 & 0.000 \\
\hline
\end{tabular}

Note: ${ }^{\star} \mathrm{df}$ between groups $=3$ and $\mathrm{df}$ within groups $=146$.

The ANOVA analysis (Table 5) showed that, for all three variables, the differences were statistically significant. In import volumes $[\mathrm{F}(3,146)=199,616 ; \mathrm{p}(0,000)]$, export $[\mathrm{F}(3,146)=196,370 ; \mathrm{p}(0,000)]$ and production $[\mathrm{F}(3,146)=158,222 ; \mathrm{p}(0,000)]$. The variable with the greatest significant difference is import volume and the highest average for this variable is presented by sub-cluster 1.3 (composed of Germany and the United Kingdom). With the additional information in Table 6, the import variable is also significant and differentiates all clusters from each other, except sub-cluster 1.1 from subcluster 1.2 .

In addition, the export volume variable is of continuing importance, and the highest average for this variable is presented by sub-cluster 1.4 (Belgium and France). This conglomerate can be sub-profiled as an exporter. Table 6 indicates that the export variable is also significant and differentiates all the clusters from each other, except subcluster 1.1 from sub-cluster 1.3. Finally, the production volume variable is also significant (Table 5) and the highest average for this variable is presented by sub-cluster 1.2 (Greece, Portugal, Poland 2005-06 and 2010, together with Romania 2006), where all the clusters are differentiated from each other, except sub-cluster 1.1 from sub-cluster 1.3 (Table 6). 
Table 6. Multiple comparisons (Bonferroni) at the second level of pre-crisis clustering (source: own elaboration based on COMTRADE, 2018)

\begin{tabular}{|c|c|c|c|c|}
\hline $\begin{array}{c}\text { Cluster } \\
i\end{array}$ & $\begin{array}{c}\text { Cluster } \\
j\end{array}$ & $\begin{array}{c}\text { Production Volume }[\mathrm{Kg}] \\
\text { Sig. }\end{array}$ & $\begin{array}{c}\text { Imports Volume }[\mathrm{Kg}] \\
\text { Sig. }\end{array}$ & $\begin{array}{c}\text { Exports Volume }[\mathrm{Kg}] \\
\text { Sig. }\end{array}$ \\
\hline \multirow{3}{*}{1.1} & 1.2 & 0.000 & 1.000 & 0.000 \\
\cline { 2 - 5 } & 1.3 & 1.000 & 0.000 & 0.298 \\
\cline { 2 - 5 } & 1.4 & 0.000 & 0.000 & 0.000 \\
\hline \multirow{2}{*}{1.2} & 1.3 & 0.000 & 0.000 & 0.000 \\
\cline { 2 - 5 } & 1.4 & 0.000 & 0.000 & 0.000 \\
\hline \multirow{2}{*}{1.3} & 1.4 & 0.000 & 0.000 & 0.000 \\
\hline
\end{tabular}

In Table 7 on the characterization of the clusters at the second level of clustering, subcluster 1.3 can be identified with an importing sub-profile. In the four sub-clusters obtained, specific production, import and export sub-profiles were able to be identified for the different European countries involved. The presence of numerous outliers in the three input variables in cluster 1.1 may indicate the possibility of applying a third level of clustering. Even if possible, clusters were able to be detected within sub-cluster 1.1, the objective of this study with respect to the classification of European countries to obtain main and secondary profiles for the European tomato consumer market can be considered concluded. Six clusters with their corresponding characterisation have been identified for the pre-crisis period.

Table 7. Characterization of the conglomerates of the second level of the pre-crisis chained cluster (source: own elaboration based on COMTRADE, 2018)

\begin{tabular}{|c|c|}
\hline $\begin{array}{c}\text { Cluster } 1.1(\mathrm{n}=110) \\
\text { Main profile }{ }^{\star} \text { Not DETERMINED }\end{array}$ & $\begin{array}{c}\text { Cluster 1.2 }(\mathrm{n}=16) \\
\text { Main profile* Not DETERMINED } \\
\text { Sub-profile PRODUCER }\end{array}$ \\
\hline $\begin{array}{l}\text { Austria. Bulgaria. Croatia. Cyprus. Czech Republic. } \\
\text { Denmark. Estonia. Finland. Hungary. Ireland. Latvia. } \\
\text { Lithuania. Luxembourg. Malta. Poland 2007-09. Sweden. } \\
\text { Romania } 2005 \text { and 2007-2010. Slovakia. Slovenia }\end{array}$ & $\begin{array}{l}\text { Greece. Portugal. Romania 2006. Poland } \\
2005-06 \text { and } 2010\end{array}$ \\
\hline $\begin{array}{c}\text { Cluster } 1.3(\mathrm{n}=12) \\
\text { Main profile }{ }^{\star} \text { Not DETERMINED } \\
\text { Sub-profile IMPORTER }\end{array}$ & $\begin{array}{c}\text { Cluster 1.4 }(\mathrm{n}=12) \\
\text { Main profile }{ }^{\star} \text { Not DETERMINED } \\
\text { Sub-profile EXPORTER }\end{array}$ \\
\hline Germany and United Kingdom & Belgium and France \\
\hline
\end{tabular}

According to the information provided by the box diagrams (Figures 6, 7 and 8), in sub-cluster 1.3 (Germany and the United Kingdom) the variable volume of imports has the most weight (Figure 7). In sub-cluster 1.4 (Belgium and France) the export volume variable has the most weight (Figure 8). Sub-cluster 1.2 (Greece, Portugal, Poland 2005-06 and 2010, together with Romania 2006) is the first mixed cluster formed by discontinuous and partial countries on a temporary basis (Figure 6). Finally, in sub-cluster 1.1 (the rest of the European countries), although the weight of one of the input variables is not as evident as in 
the previous clusters, it can be seen (Figure 7) that the volume of imports variable now has greater weight than the other variables. For the characterisation of these four sub-clusters, the information previously obtained was added to the profile inherited from the first level of clustering (Table 7).

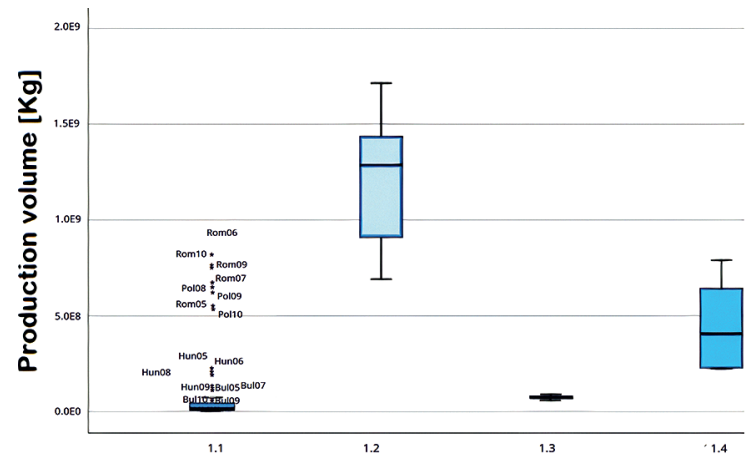

Figure 6. Box diagram of the pre-crisis production variable according $t$ o the clusters of the second two-stage clustering level (source: own elaboration)

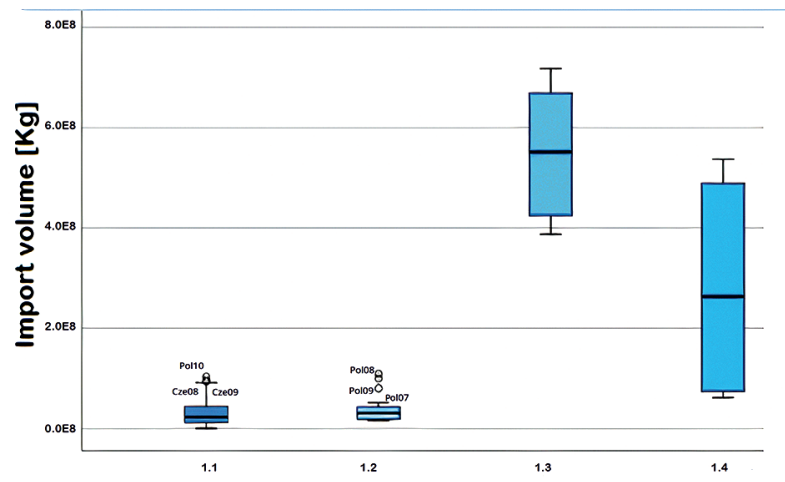

Figure 7. Box diagram of the pre-crisis import variable according to the clusters of the second two-stage clustering level (source: own elaboration)

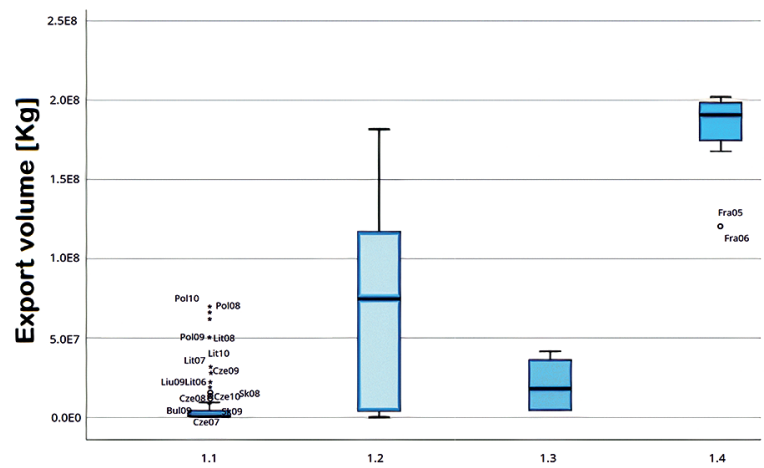

Figure 8. Box diagram of the pre-crisis export variable according to the clusters of the second two-stage clustering level (source: own elaboration) 


\subsubsection{Post-crisis period (2011-2016)}

In the post-crisis sample, at the first level of clustering, three clusters were obtained with the same composition and quality index than pre-crisis period. At the first cluster level, the analysis of variance ANOVA was undertaken and the differences between the three clusters were statistically significant in only two of the variables, export volumes $[\mathrm{F}(2,165)=1,221,594$; $\mathrm{p}(0,000)]$ and production $[\mathrm{F}(2,165)=313,831 ; \mathrm{p}(0,000)]$ (Table 8$)$.

Table 8. Cluster centres and ANOVA for two-stage analysis at the first post-crisis clustering level (source: own elaboration based on COMTRADE, 2018)

\begin{tabular}{|l|c|c|c|c|c|}
\hline \multirow{2}{*}{ Volumes [kg] } & \multicolumn{3}{|c|}{ Mean (Standard deviation) } & \multicolumn{2}{c|}{ ANOVA } \\
\cline { 2 - 6 } & $\begin{array}{c}\text { Cluster 1 } \\
(n=150)\end{array}$ & $\begin{array}{c}\text { Cluster 2 } \\
(n=6)\end{array}$ & $\begin{array}{c}\text { Cluster 3 } \\
(n=12)\end{array}$ & $\mathrm{F}^{*}$ & Sig. \\
\hline Production & $\begin{array}{c}226,690,800 \\
(397,040,099)\end{array}$ & $\begin{array}{c}5,889,305,333 \\
(459,748,754)\end{array}$ & $\begin{array}{c}2,603,479,417 \\
(1,852,251,087)\end{array}$ & 313,831 & 0.000 \\
\hline Import & $\begin{array}{c}103,086,651 \\
(179,774,142)\end{array}$ & $\begin{array}{c}126,599,374 \\
(9,868,058)\end{array}$ & $\begin{array}{c}187,632,170 \\
(59,997,822)\end{array}$ & 1,370 & 0.255 \\
\hline Export & $\begin{array}{c}33,581,652 \\
(66,125,568)\end{array}$ & $\begin{array}{c}106,636,062 \\
(4,851,070)\end{array}$ & $\begin{array}{c}1,021,985,513 \\
(86,049,658)\end{array}$ & $1,221,594$ & 0.000 \\
\hline
\end{tabular}

Note: ${ }^{\star} \mathrm{df}$ between groups $=2$ and $\mathrm{df}$ within groups $=165$.

As can be seen in Table 8, at the first level of clustering, the variable with the greatest significance difference value is export by cluster 3 (composed of the Netherlands and Spain), so that cluster 3 can again be identified as having a main export profile. According to the information provided by the Bonferroni Test (Table 9), all the clusters are differentiated by the export variable, except for clusters 1 and 2. The production variable continues to be of significant importance and the highest average for this variable is presented by cluster 2 (Italy) and all the clusters are differentiated from each other (Table 9). This conglomerate could be mainly profiled as a producer and secondarily as an exporter.

Table 9. Multiple comparisons (Bonferroni) at the first level of post-crisis clustering (source: own elaboration based on COMTRADE, 2018)

\begin{tabular}{|c|c|c|c|c|}
\hline $\begin{array}{c}\text { Cluster } \\
i\end{array}$ & $\begin{array}{c}\text { Cluster } \\
j\end{array}$ & $\begin{array}{c}\text { Production Volume }[\mathrm{Kg}] \\
\text { Sig. }\end{array}$ & $\begin{array}{c}\text { Imports Volume }[\mathrm{Kg}] \\
\text { Sig. }\end{array}$ & $\begin{array}{c}\text { Exports Volume }[\mathrm{Kg}] \\
\text { Sig. }\end{array}$ \\
\hline \multirow{2}{*}{1} & 2 & 0.000 & 1.000 & 0.028 \\
\cline { 2 - 5 } & 3 & 0.000 & 0.307 & 0.000 \\
\hline 2 & 3 & 0.000 & 1.000 & 0.000 \\
\hline
\end{tabular}

At this first cluster level, no temporarily differentiated profiles were found in the post-crisis period, as was the case for the pre-crisis period. That is, the entire economic periods of each country were grouped within the same clusters. The characterization of the clusters of the first level of post-crisis chained cluster coincide with pre pre-crisis table (Table 4). 
In the box diagrams for cluster groups in the three input variables (Figures 9, 10 and 11) a high number of outliers in cluster 1 is observed. For this reason, and in order to achieve a more nuanced classification, the same classification technique was again applied to the largest cluster in order to obtain sub-profiles from other groups of countries that maximise their inter-group differences and minimise their intra-group ones. In other words, two-stage clusters were created and two levels of clustering were obtained (Figure 2).

Through the analysis of the box diagrams (Figures 9, 10 and 11), each cluster identified with a main profile can be characterized. In cluster 2 (Italy) the production volume variable again has the most weight (Figure 9). In cluster 3 (Netherlands and Spain) the export volume variable has the most weight (Figure 11). In cluster 1 (other European countries), although the weight of one of the input variables is not as evident as in the previous clusters, it can be seen (Figure 10) that the import volume variable has greater weight than the other variables.

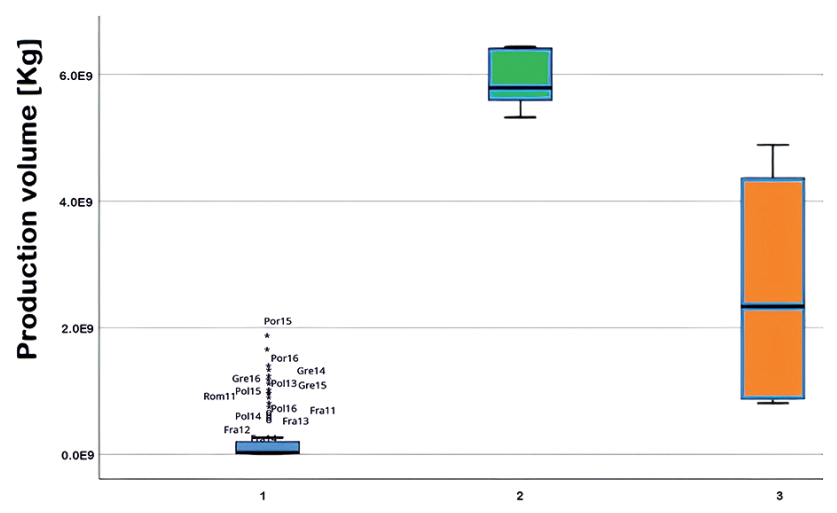

Figure 9. Post-crisis box diagram of production variable according to the clusters of the first two-stage clustering level (source: own elaboration)

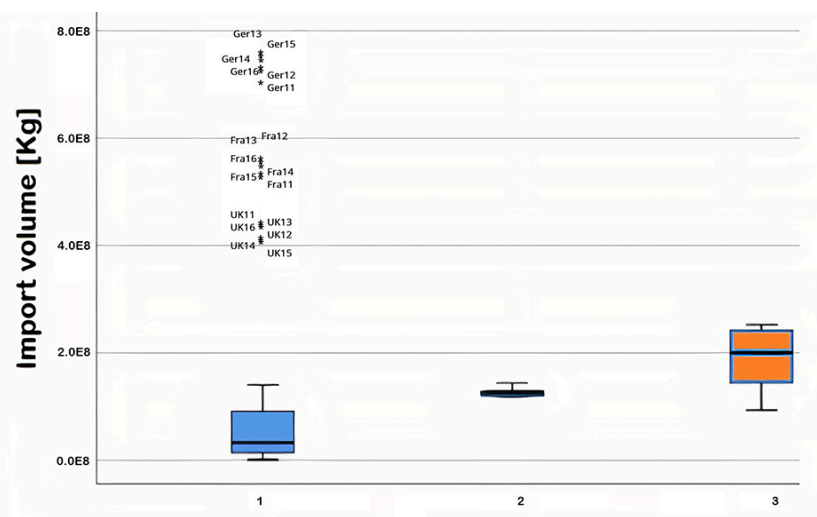

Figure 10. Post-crisis box diagram of import variable according o the clusters of the first two-stage clustering level (source: own elaboration) 


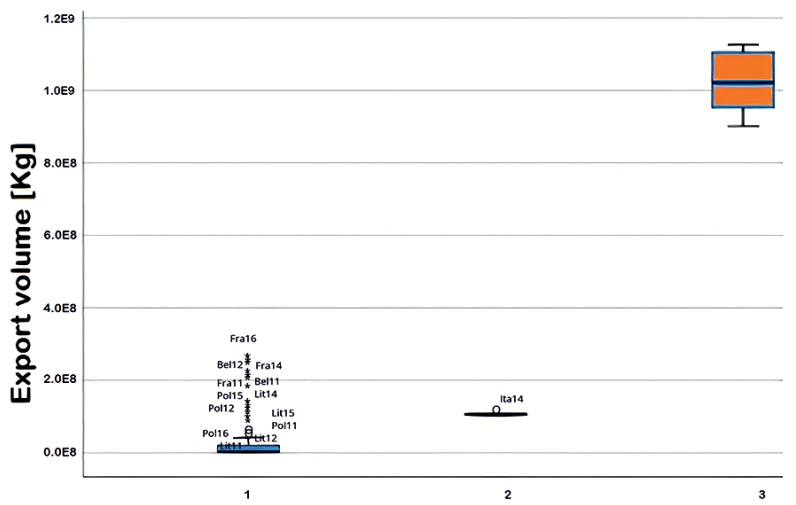

Figure 11. Post-crisis box diagram of export variable according to the clusters of the first two-stage clustering level (source: own elaboration)

At the second level of clustering, the algorithm also automatically determined the number of clusters to be three (for the selection of cases from cluster 1 of the first cluster level). The quality of the cluster was lower in this case (0.7), although the solution obtained remained satisfactory (Kaufman \& Rousseeuw, 1990).

In the ANOVA analysis (Table 10) it was found that the differences in the three variables were statistically significant, export volumes $[\mathrm{F}(2,147)=310,463 ; \mathrm{p}(0,000)]$, import $[\mathrm{F}(2,147)=202,291 ; \mathrm{p}(0,000)]$ and production $[\mathrm{F}(2,147)=12,682 ; \mathrm{p}(0,000)]$.

Table 10. Cluster centres and ANOVA for two-stage analysis at the s post-crisis clustering level (source: own elaboration based on COMTRADE, 2018)

\begin{tabular}{|l|c|c|c|c|c|}
\hline \multirow{2}{*}{$\begin{array}{c}\text { Volumes } \\
{[\mathrm{Kg}]}\end{array}$} & \multicolumn{3}{|c|}{ Mean (Standard deviation) } & \multicolumn{2}{c|}{ ANOVA } \\
\cline { 2 - 6 } & $\begin{array}{c}\text { Cluster } 1.1 \\
(n=123)\end{array}$ & $\begin{array}{c}\text { Cluster } 1.3 \\
(n=12)\end{array}$ & $\begin{array}{c}\text { Cluster } 1.4 \\
(n=15)\end{array}$ & $\mathrm{F}^{*}$ & Sig. \\
\hline Production & $\begin{array}{c}185,938,658 \\
(359,264,098)\end{array}$ & $\begin{array}{c}84,501,583 \\
(11,387,109)\end{array}$ & $\begin{array}{c}674,609,733 \\
(553,177,826)\end{array}$ & 12,682 & 0.000 \\
\hline Import & $\begin{array}{c}38,035,976 \\
(36,068,996)\end{array}$ & $\begin{array}{c}571,634,888 \\
(170,267,661)\end{array}$ & $\begin{array}{c}261,663,599 \\
(239,901,370)\end{array}$ & 202,291 & 0.000 \\
\hline Export & $13,914,616$ & $\begin{array}{c}12,938,000 \\
(8,949,962)\end{array}$ & $\begin{array}{c}211,366,267 \\
(40,645,194)\end{array}$ & 310,463 & 0.000 \\
\hline
\end{tabular}

Note: ${ }^{\star} \mathrm{df}$ between groups $=2$ and $\mathrm{df}$ within groups $=147$.

The variable with the greatest significant difference is export volume (Table 10) and the greatest average for this variable is presented by sub-cluster 1.4 (composed of Belgium, France and Portugal since 2014). Therefore, at the second level of clustering, sub-cluster 1.4 can be identified with an export sub-profile. A difference can be seen between all the clusters, except between cluster 1.1 and 1.3 (Table 11). In the ANOVA analysis, the volume of imports variable continues to be important, and the highest average for this variable is presented by sub-cluster 1.3 (Germany and the United Kingdom). This conglomerate can be sub-profiled as an importer, with a difference between all the clusters (Table 11). With the additional 
information in Table 10, finally, the variable production is also significant, and in cluster 1.1. it is the variable that has the greatest weight.

Table 11. Multiple comparisons (Bonferroni) at the second level of post-crisis clustering (source: own elaboration based on COMTRADE, 2018)

\begin{tabular}{|c|c|c|c|c|}
\hline $\begin{array}{c}\text { Cluster } \\
i\end{array}$ & $\begin{array}{c}\text { Cluster } \\
j\end{array}$ & $\begin{array}{c}\text { Production Volume }[\mathrm{Kg}] \\
\text { Sig. }\end{array}$ & $\begin{array}{c}\text { Imports Volume }[\mathrm{Kg}] \\
\text { Sig. }\end{array}$ & $\begin{array}{c}\text { Exports Volume }[\mathrm{Kg}] \\
\text { Sig. }\end{array}$ \\
\hline \multirow{2}{*}{1.1} & 1.3 & 1.000 & 0.000 & 1.000 \\
\cline { 2 - 5 } & 1.4 & 0.000 & 0.000 & 0.000 \\
\hline 1.3 & 1.4 & 0.000 & 0.000 & 0.000 \\
\hline
\end{tabular}

In the three sub-clusters obtained, namely production, import and export sub-profiles could be identified for the different European countries involved. Temporally differentiated profiles were found in the period analyzed (2014-2016) for the case of Portugal.

The presence of numerous outliers in the three input variables in cluster 1.1 may indicate the possibility of applying a third level of clustering. Although possible clusters could be detected within sub-cluster 1.1 , the objective of this study with respect to the classification of European countries to obtain profiles for the European tomato consumer market can be considered concluded. Five clusters with their corresponding characterization were found (Table 12). In comparison with the pre-crisis results (Table 7), in the post-crisis period the countries of cluster 1.2. have undergone a transformation of post-crisis sub-profile, presenting dissimilar behaviour. Greece, Romania 2006 and Poland 2005-06 and 2010 were moved to cluster 1.1 characterized as countries with a producer sub-profile. However, Portugal changed from a pre-crisis producer sub-profile (cluster 1.2 in Table 7 ) to a post-crisis exporter subprofile together with France and Belgium (cluster 1.4 in Table 12).

Table 12. Characterization of the clusters of the second level of post-crisis chained cluster (source: own elaboration based on COMTRADE 2018)

\section{Cluster $1.1(n=123)$ \\ Main profile Not DETERMINATED \\ Sub-profile PRODUCER}

Austria. Bulgaria. Croatia. Cyprus. Czech Republic. Denmark. Estonia. Finland. Greece. Hungary. Ireland. Latvia. Lithuania. Luxembourg. Malta. Poland. Portugal 2011-2013. Romania. Slovakia. Slovenia. Sweden

\begin{tabular}{|c|c|}
\hline $\begin{array}{c}\text { Cluster } 1.3(n=12) \\
\text { Main profile Not determined } \\
\text { Sub-profile IMPORTER }\end{array}$ & $\begin{array}{c}\text { Cluster 1.4 }(n=15) \\
\text { Main profile Not determined } \\
\text { Sub-profile EXPORTER }\end{array}$ \\
\hline Germany and the United Kingdom & Belgium, France, and Portugal 2014-16 \\
\hline
\end{tabular}

With regards to the box diagrams (Figures 12, 13 and 14), in sub-cluster 1.4 (Belgium and France) the export volume variable has the most weight (Figure 14). Sub-cluster 1.4 presents an outlier for the case of Portugal in the years 2014 and 2016. In sub-cluster 1.1 (other European countries), although the weight of one of the input variables is not as evident as in the previous clusters, it can be seen (Figure 9) that the variable volume of production now has 
greater weight than the other variables. For the characterisation of these three sub-clusters, the information previously obtained is attached to the profile inherited from the first level of clustering (Table 4).

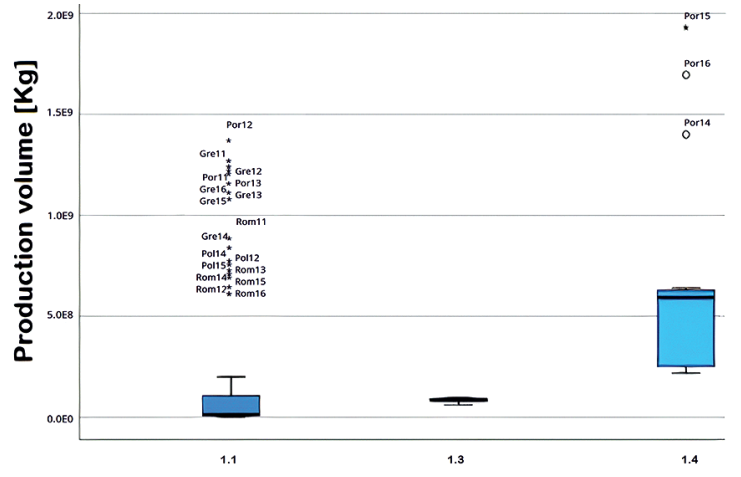

Figure 12. Post-crisis box diagram of production variable according to the clusters of the second two-stage clustering level (source: own elaboration)

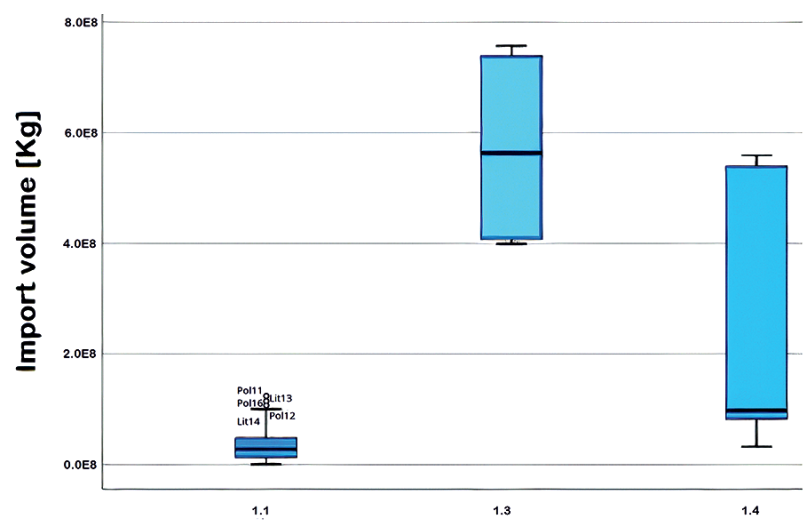

Figure 13. Post-crisis box diagram of import variable according to the clusters of the second two-stage clustering level (source: own elaboration)

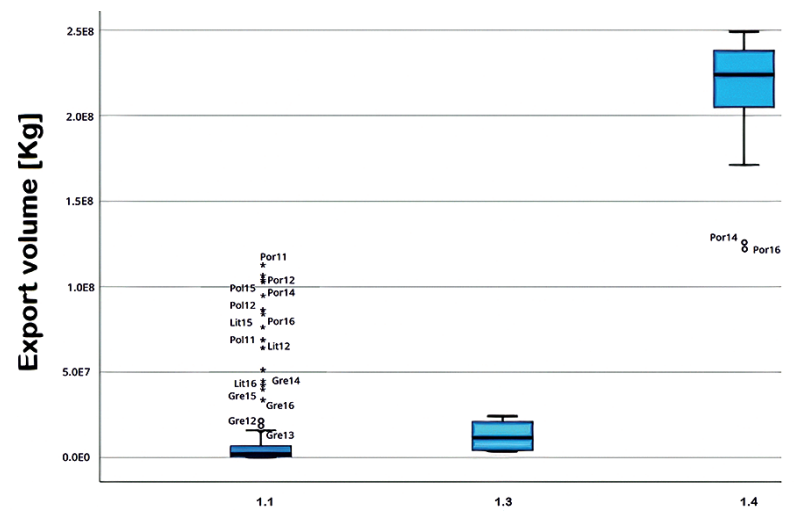

Figure 14. Post-crisis box diagram of export variable according to the clusters of the second two-stage clustering level (source: own elaboration) 
The results obtained through Lafay's economic indicators coincide in the group of competing exporting countries, Spain, the Netherlands, Belgium and Portugal. However, Lafay's indices do not detect France as having an export profile, but they do detect a change of profile in Greece from an importer to an exporter, which is not considered by the multivariate cluster analysis. Lafay's indices show divergent results from Italy.

\section{Discussion}

According to Dussel (2001), competitiveness reflects the dynamic insertion of the products of the countries selected, which depends both on the performance of the export structure compared with its competitors (supply), as well as the dynamism of international trade or specific target markets or group of clients (demand). The main objective of this study was to provide a quick and simple method of implementation to identify countries and classify (producer or/and exporter or/and importer) them in such a way as to form heterogeneous groups, composed of elements that are homogeneous among themselves, specifically in the European tomato market.

In a global context where competitiveness has become a route to economic survival, the study of the composition of the target (or reference) market is an unavoidable step. It should even be carried out before obtaining competitiveness indices in the countries participating in international trade of agricultural products (goods or services) or other productive sectors. To understand the market goes far beyond recognizing it. According to Pérez and Pérez (2006), the knowledge of the market means to have delved into its essence and to be able to synthesize and to analyze: its structure, its characteristics and its conditioners, in the sense of improving the commercialization decisions that affect it. Therefore, the identification of country profiles within a consumer market is a key stage before making decisions on the foreign trade policies of exporting countries.

The first level of clustering has an unequivocal correspondence with the reality of the tomato trade in the European market in both pre- and post-crisis periods of analysis. Cluster 3, smaller and consisting only of Italy, is mainly characterised by the input variable of production volume. This result is validated by the data provided by the FAOSTAT (2018), since it places Italy as the European leader in tomato production in Europe (Figure 2). Italy's role as an exporter of fresh tomatoes is secondary, because most of its production, over $86 \%$, is dedicated to the food processing industry for the manufacture of tomato-based sauces and food products (Montero Tortajada, 2015; Boccia et al., 2019). The cluster constituted by the Netherlands and Spain is characterized mainly by the input variable of export volume, as indicated De Pablo Valenciano et al. (2020). The formation of this group is validated by Spain's leadership as an exporter in the European market until 2009 and its replacement by the Netherlands to date (Figure 5). Although both countries are leaders in the European market, recent analyses indicate that they are losing relevance in the world trade of tomatoes as their exports of this vegetable are falling compared to those of Mexico and Morocco, which have increased the presence of their tomatoes on the world stage, according to data produced by Hortoinfo (2017), from the Statistics Division of the United Nations Organization (UN), code HS0702 (fresh and chilled tomatoes). The largest cluster obtained at the first level of 
clustering, although it is mainly characterized by the input variable of import volume, the characteristics of the participant countries are so varied that it is necessary to apply a cluster analysis again to this group on an individual level to break it down into smaller groups and with more homogeneous elements.

At the second level of clustering applied only to the largest group at the first level of clustering, four clusters are formed in the pre-crisis period and three clusters in the post-crisis period with real significance in the European tomato market. In both pre- and post-crisis periods, two clusters are identical, sub-cluster 1.4 formed by Germany and the United Kingdom, while maintaining its main import profile inherited from the more numerous cluster at the first level of clustering, presents an import sub-profile, reaffirming its characterisation as net importers. Medina Vega (2015) in the report on the German fruit and vegetable market indicates that both the German and British markets are the main European destination markets and maintains that Germany absorbs $30 \%$ of all tomato imported into the EU and reveals the growing trend of this market which still does not seem to have found a balance in its demand and is still growing. Additionally, the report by Ruiz Franco and Falcón Soria (2015), identifies the British market as the third largest tomato import market in Europe, showing a tendency to growth in tomato consumption. Although there are also signs that it has already reached its consumption ceiling, the $80 \%$ of tomatoes consumed are imported for the British market (Frankowska et al., 2019). The sub-cluster 1.3 formed by France and Belgium also inherits the main profile of the largest cluster at the first level of clustering. But in this case, the second level of clustering reveals an export sub-profile. In Proexport's report (2009), France is the second most important market in the European Union in terms of volume and is mainly supplied by an extracommunity supplier of tomatoes, Morocco (Berahab \& Dadush, 2020). In France it is worth noting the high degree of concentration and the significant size of the distribution groups, the majority of which have a high degree of international presence, facilitating the marketing of tomatoes outside the French borders. According to De Pablo-Valenciano et al. (2016), Belgium is identified by its commercial strategy in re-exporting tomatoes to other Member States and third countries, which is not contradictory with the increase in national production. Belgium does act as a re-exporter to outside the EU and in particular to the Russian Federation. In this sub-cluster 1.4, in the post-crisis period, Portugal has become a re-exporter since 2014 although there are precedents for this change in the economic literature. However, this information is relevant to bear in mind when forming the group of competing exporting countries in the European tomato market. The main competitors, Spain and the Netherlands, are joined by France and Belgium and with the results of the multivariate cluster analysis a new incorporation, Portugal, has been detected since 2014. Moreover, Portugal has increased to 30\% the area of tomato production for processing (Cepeda et al., 2019).

The application of these indices by Lafay has the disadvantage that they do not detect profiles of producing countries, i.e. supply to internal consumption with their own production, both for fresh consumption and for their processing industry. Moreover, Lafay's economic indexes only categorise a single variable in the profile of countries, importers or exporters exclusively, making it impossible to detect sub-profiles or combined profiles. In the Italian case, the (Lafay, 1979) was unspecified for an export or import country profile identification 
in the pre-crisis period, and some inconsistent profiles were observed between both indexes in the postcrisis period.

\section{Conclusions}

The application of the two versions of Lafay's economic index only offer a dichotomous classification of countries, net importers or net exporters, and do not allow the determination of production profiles or combinations of profiles and sub-profiles. This work uses a methodology called multilevel chained clustering, which makes it possible to determine country profiles and sub-profiles, combining the three variables of apparent consumption (production, export and import) of a product, therefore adjusting better to the reality of each country.

Through both Lafay's indexes, import and export profiles were obtained, coinciding in all cases with the exception of Italy where there is a divergence of criteria between the indices applied. In the case of the Netherlands, one of the indices is very sensitive to changes in the variables. What is more, both indices detected a change in the post-crisis profile of Greece from an importer to an exporter.

The results obtained through Lafay's economic indicators coincide with the multivariate analysis of conglomerates in the group of competing exporting countries, Spain, the Netherlands, Belgium and Portugal. However, they do not detect France as having an export sub-profile and highlight the change in the profile of Greece from an importer to an exporter, which was not considered by the multivariate cluster analysis.

The main contribution of this work is to the knowledge of the European market of tomatoes and it can be stated that, for example, Spain's direct competitor is the Netherlands, its clients are Germany and the United Kingdom, and finally France and Belgium besides being clients can exercise the role of intermediaries, so they are also potential competitors. They are joined by Portugal which has undergone a post-crisis shift from a sub-producer profile to an export sub-profile from 2014. In summary, the results obtained through the two-stage chained clustering methodology can objectively guide the selection of the group of competing economies within the European tomato market. According to the results achieved in this study, the group of competitors currently comprising Spain, the Netherlands, Belgium, France and Italy can be specified. In the near future, if current trade trends in Portugal continue, it is possible that the Portuguese economy will be incorporated into the group of competing economies in the European tomato market.

This study presents several practical implications. On the one hand, the application of two-stage clustering allows heterogeneous groups to be obtained objectively without decision-making at the cut-off level for the formation of heterogeneous groups as in the other clustering methods. On the other hand, the results obtained by the more specific profiles and sub-profiles provided by multilevel chain-linked clustering provide relevant information for decision-making during the planning of positioning strategies for an exporting country in the European market.

As limitations of the research, the use of the COMTRADE database involves consolidated data, but as they are aggregated at different levels and the data collection is not homogenized for all countries. In this vein, the data, like any source of information, is not free from er- 
rors and omissions. Specifically, in the COMTRADE trade statistics, most countries include re-exports as exports, transactions may be recorded in different time periods as a result of delayed shipments of goods between countries, and exchange rate fluctuations are not always recorded correctly.

Future research lines could be derived from this study. First, the methodological proposal of multilevel clustering, chained at two levels, should be repeated with other types of hierarchical clustering procedures to check the validity of the results obtained. Second, the extension to the analysis of other regional trade agreements to provide a global picture of competing groups and customers in the global tomato market. Third, it could also be applied to other fruit and vegetable markets of interest.

\section{Acknowledgements}

The authors acknowledge the support for the Department of Economy and Business of the University of Almeria.

\section{Funding}

The manuscript is supported by the author's personal funds. The authors agree to pay APC if the manuscript is accepted after a peer review process.

\section{Author contributions}

$\mathrm{CU}$ and GA conceived the study and were responsible for the design and development of the data analysis. CU, CG, PV and CB were responsible for data collection and analysis. $\mathrm{CU}$ and $\mathrm{CA}$ were responsible for data interpretation. $\mathrm{CU}$ and $\mathrm{CB}$ were in charge of the writing and supervision of the paper.

\section{Disclosure statement}

The authors declare that they have no competing financial, professional, or personal interests.

\section{References}

Agencia de Gestión agraria y Pesquera de Andalucía. (2014). Análisis del origen de las importaciones hortícolas protegidos a la UE: Pimiento. Junta de Andalucía.

Álvarez, A. F. (2020). Moroccan agricultural products in the single market: Trade flows and competitiveness. Studies of Applied Economics, 38(2). https://doi.org/10.25115/eea.v38i2.3236

Bacher, J., Wenzig, K., \& Vogler, M. (2004). SPSS TwoStep Cluster - a first evaluation. Friedrich-Alexander-Universität Erlangen-Nürnberg, Lehrstuhl für Soziologie.

https://nbn-resolving.org/urn:nbn:de:0168-ssoar-327153

Bashimov, G. (2016). Turkey's export performance of tomato and competitiveness. Alinteri Journal of Agriculture Sciences, 31(2), 1-8. https://doi.org/10.28955/alinterizbd.319451 
Berahab, R., \& Dadush, U. (2020). Has Morocco Benefited from the Free Trade Agreement with the European Union? (Research Paper). Policy Center for the New South (Morocco). https://www.policycenter.ma/sites/default/files/RP\%20-\%2020-03\%20\%28Rim\%20\%26\%20Dadush\%29\%20\%281\%29.pdf

Boccia, F., Di Donato, P., Covino, D., \& Poli, A. (2019). Food waste and bio-economy: A scenario for the Italian tomato market. Journal of Cleaner Production, 227, 424-433.

https://doi.org/10.1016/j.jclepro.2019.04.180

Capobianco Uriarte, M. M., Aparicio, J., \& De Pablo Valenciano, J. (2017). Analysis of Spain's competitiveness in the European tomato market: An application of the Constant Market Share method. Spanish Journal of Agricultural Research, 15(3), e0113. https://doi.org/10.5424/sjar/2017153-10629

Capobianco Uriarte, M. M., De Pablo Valenciano, J., \& Milan Garcia, J. (2020). Tendencias comerciales poscrisis en el mercado europeo de tomates. Información Técnica Económica Agraria, 116(2), 161-183. https://doi.org/10.12706/itea.2019.023

Cepeda, M. S., Martins, M. F., De Oliveira, L., \& Bernabéu, R. (2019). Evolution of the processed tomato sector in Portugal and Spain: Comparative analysis. Emirates Journal of Food and Agriculture, 31(6), 470-476. https://doi.org/10.9755/ejfa.2019.v31.i6.1970

Chiu, T., Fang, D., Chen, J., Wang, Y., \& Jeris, C. (2001). A robust and scalable clustering algorithm for mixed type attributes in large database environment. In Proceedings of the $7^{\text {th }}$ ACM SIGKDD International Conference on Knowledge Discovery and Data Mining (pp. 263-268). https://doi.org/10.1145/502512.502549

COMTRADE. (2018). Bases de datos de comercio internacional de la Organización de las Naciones Unidas. www.comtrade.org

Crespo Faustino, H. (1989). A propósito de polémica entre Ballence-Forstner-Murray e Bowen sobre a medida da ventagem comparativa (Documento de Trabajo No. 8). Instituto Superior de Economía, Lisboa, Portugal.

De Pablo Valenciano, J., \& Giacinti Battistuzzi, M. A. (2012). Analytical model for the global consumption of tomatoes - The Spanish case. African Journal of Agricultural Research, 7(15), 2328-2335. https://doi.org/10.5897/AJAR11.529

De Pablo Valenciano, J., Giacinti Battistuzzi, M. A., \& Garcia, T. (2016). Estados claves en el comercio intracomunitario del tomate en la Unión Europea. Información Técnica Económica Agraria, 112(4), 458-477. https://doi.org/10.12706/itea.2016.028

De Pablo Valenciano, J., Giacinti Battistuzzi, M. A., Tassile, V., \& Azcárate, T. (2017). Changes in the business model for Spanish fresh tomato trade. Spanish Journal of Agricultural Research, 15(1), 1-11. https://doi.org/10.5424/sjar/2017151-9309

De Pablo Valenciano, J., Román Sánchez, I. M., \& Uribe Toril, J. (2012). España: competitividad revelada en el caso del tomate. Revista Comercio Exterior, 62(1), 51-59. http://revistas.bancomext.gob.mx/rce/magazines/138/5/VOL._62-1_Espa\%C3\%B1a.pdf

De Pablo Valenciano, J., Torres Arriaza, J. A., Uribe-Toril, J., \& Ruiz-Real, J. L. (2020). Triangulation Applied to the Intra-European Union Tomato Market. Complexity, 2020, ID 6535927. https://doi.org/10.1155/2020/6535927

Durán Lima, J. E., \& Alvarez, M. (2011). Manual de comercio exterior y política comercial: nociones básicas, clasificaciones e indicadores de posición y dinamismo. Documento de Proyecto.

Dussel, E. (2001). Un análisis de la competitividad de las exportaciones de prendas de vestir de Centroamérica utilizando los programas y la metodología CAN y MAGIC [An analysis of the competitiveness of clothing items from Central America using CAN and MAGIC programmes and methodology] (CEPAL, Serie: Estudios y perspectivas No. 1, pp. 10-11). Naciones Unidas.

FAOSTAT. (2018). Bases de datos de la Organización de las Naciones Unidas. www.faostat.org Fideicomisos Instituidos en Relación a la Agricultura. (2019). Informe tomate rojo 2019. 
https://www.inforural.com.mx/wp-content/uploads/2019/06/Panorama-Agroalimentario-Tomaterojo-2019.pdf

Frankowska, A., Jeswani, H. K., \& Azapagic, A. (2019). Environmental impacts of vegetables consumption in the UK. Science of The Total Environment, 682, 80-105.

https://doi.org/10.1016/j.scitotenv.2019.04.424

Hair, J., Black, W., Babin, B., \& Anderson, R. (2018). Grouping data with cluster analysis. In Multivariate data analysis ( $8^{\text {th }} \mathrm{ed}$.). Cengage.

Hortoinfo. (2017). Holanda y España pierden relevancia frente a México y Marruecos en el comercio de tomate. http://www.hortoinfo.es/index.php/5618-export-mund-tm-120517

Jurkènaite, N., \& Paparas, D. (2020). Towards better understanding of vegetable market functioning: The Lithuanian cases of fresh tomatoes and cucumbers. Outlook on Agriculture, 49(2), 163-171. https://doi.org/10.1177/0030727019866208

Kaufman, L., \& Rousseeuw, P. (1990). Finding groups in data: An introduction to cluster analysis. John Wiley \& Sons. https://doi.org/10.1002/9780470316801

Lafay, G. (1979). Dynamique de la specialisation international. Economica.

Lafay, G. (1992). The measurement of revealed comparative advantages. In International trade modelling (pp. 209-234). Springer.

Lombardi, A., Verneau, F., \& Lombardi, P. (2016). Development and trade competitiveness of the Italian Tomato Sector. Agricultural Economics Review, 17(1), 5-19.

Medina Vega, C. (2015) Estudio de mercado. El mercado de frutas y hortalizas en Alemania 2015. Oficina ICEX.

Montero Tortajada, M. (2015). El mercado de las frutas y hortalizas frescas en Italia. ICEX Oficina Económica y Comercial de la Embajada de España en Milán.

OECD/FAO. (2019). Agricultural Outlook 2019-2023. OECD Publishing.

Pérez Mesa, F. J., Pérez Mesa, J. C., \& Valera Martínez, D. L. (2018). Viabilidad comercial del tomate español en la Unión Europea. Información Técnica Económica Agraria, 114(4), 378-397. https://doi.org/10.12706/itea.2018.023

Pérez, C. (2011). Técnicas de segmentación. Conceptos, herramientas y aplicaciones. Madrid: Garceta Grupo Editorial. https://www.casadellibro.com/libro-tecnicas-de-segmentacion-conceptos-herramientas-y-aplicaciones/9788492812196/1897112

Pérez, D., \& Pérez, I. (2006). El conocimiento del mercado: análisis de clientes, intermediarios y competidores. Madrid, Spain. Escuela de Organización Industrial.

Proexport. (2009). Principales mercados europeos de destino. https://www.proexport.es/wp-content/uploads/2019/08/200972314464704_Capitulo_I.pdf

Rubio-Hurtado, M., \& Vila-Baños, R. (2017). Analysis of two-step clusters with SPSS. Revista d'Innovació i Recerca en Educació, 10(1), 118. https://revistes.ub.edu/index.php/REIRE/article/view/reire2017.10.11017

Ruiz Franco, I., \& Falcón Soria, V. (2015). El mercado hortofrutícola en el Reino Unido. ICEX Oficina Económica y Comercial de la Embajada de España en Londres. http://www.agem.mercabarna.com/ FICHA-PAIS/El-Mercado-Hortofruticola-en-el-Reino-Unido.pdf

Smutka, L., Maitah, M., \& Svatos, M. (2018). Changes in the Czech agrarian foreign trade competitiveness - different groups of partners' specifics. Agricultural Economics (Czech Republic), 64(9), 399-411. https://doi.org/10.17221/399/2016-AGRICECON

Trejos, A. (2008). Instrumentos para la evaluación del impacto de acuerdos comerciales internacionales: aplicaciones para países pequeños en América Latina. Serie Estudios y Perspectivas No. 110. México D.F.: Naciones Unidas. https://digitallibrary.un.org/record/675122

World Trade Organization. (2014). World trade report 2014. https://www.wto.org/english/res_e/booksp_e/world_trade_report14_e.pdf 